ISSN 2526-4265

e-ISSN: 2526-9623

\title{
A Extinção da Punibilidade pelo Pagamento nos Crimes Tributários à luz da Análise Econômica do Direito: UM estímulo À SONEGAÇÃo FISCAL NO BRASIL?
}

Rodrigo Luís Ziembowicz ${ }^{1}$

\section{Resumo}

O texto analisa a extinção da punibilidade pelo pagamento nos delitos tributários, à luz da análise econômica do direito, face às previsões atualmente contidas na legislação brasileira. Procura-se verificar, sob os prismas da criminologia e principalmente da Economic Analysis of Law, se a possibilidade de livrar-se da pena no Brasil, desde que o pagamento da dívida fiscal seja realizado antes do trânsito em julgado da condenação penal, estimula a correta prestação de informações e o pagamento do débito tributário apurado pelo Fisco ou, ao contrário, incentiva o contribuinte a sonegar informações sobre a ocorrência de fatos geradores e evitar fraudulentamente o recolhimento de tributos. Partindo-se do conhecimento de que os contribuintes, principalmente as grandes empresas, ponderam os custos, os riscos e os benefícios de cada uma das suas opções ao tomarem suas decisões, numa evidente conduta racional maximizadora, serão analisados os mais importantes fatores sopesados pelos contribuintes ao escolherem entre o cometimento ou não dos crimes tributários.

Palavras-chave: Crimes Tributários. Extinção da Punibilidade pelo Pagamento. Análise Econômica do Direito.

\section{Abstract}

The text analyzes the extinction of criminal liability in tax crimes by the payment of the debt, under the light of the economic analysis of the law and the Brazilian legislation. Under the prism of criminology and especially of the Economic Analysis of Law, it will be verified if the possibility of the extinction of criminal liability by paying the tax debt, before the criminal conviction, stimulates the correct provision of information and the payment of the tax debit determined by the Treasury or, on the contrary, it encourages the taxpayer to avoid the occur-

1 Delegado de Polícia Federal. Mestre em Direito pela Universidade Católica de Brasília. 
rence of tax-generating facts and to fraudulently avoid the payment of taxes. The taxpayers, especially large corporations, weigh the costs, risks and benefits of each of their options to make their decisions, in an obvious rational maximizing behavior, the most important factors weighted by taxpayers will be analyzed when choosing between whether or not to commit tax crimes.

Keywords: Tax Crimes. The extinction of criminal liability in tax crimes by the payment. Economic Analysis of Law.

\section{INTRODUÇÃo}

Este estudo se destina a examinar os delitos fiscais e a extinção da punibilidade penal pelo pagamento do débito tributário, sob os prismas da criminologia e, principalmente, da análise econômica do direito, evidenciando-se as escolhas racionais realizadas pelos criminosos que praticam esta espécie de delito, além de analisar as consequências da política criminal utilizada atualmente.

Naquilo que se refere à Criminologia, compreendida como ciência que examina o comportamento criminoso e a reação social que ele causa, pode-se asseverar que objetiva realizar o estudo empírico da criminalidade, ou seja, as ações ou omissões (penalmente) sancionadas em um certo tempo e espaço. Recentemente, passou a avaliar também o autor e a vítima, concedendo maior importância à necessidade de prevenir a ocorrência do crime, de reparar o dano causado e de ressocializar o delinquente.

Quanto à análise econômica do direito, deve-se levar em consideração que, efetivamente, as condutas criminosas previstas nos delitos fiscais (em uma acepção lata, incluindo-se os delitos previdenciários) visam essencialmente ao não recolhimento de tributos previstos nas normas. Assim, o infrator, evidentemente, 
almeja um resultado econômico, utilizando a fraude para evitar a tributação e, assim, aumentar o respectivo patrimônio privado. O autor é o contribuinte fraudador e as vítimas são o Erário Público (de forma imediata) e a sociedade como um todo (de modo mediato), evidenciando a estreita relação (ou interdisciplinaridade) da Criminologia com a Análise Econômica do Direito (AED).

De fato, deve-se compreender a AED como uma metodologia científica que utiliza as mais diversas técnicas empíricas e teóricas da economia para aperfeiçoar a compreensão e mensurar o alcance do direito, aprimorando e avaliando a aplicação das normas jurídicas e, especialmente, analisando os resultados e as consequências da legislação adotada nas diferentes searas do ordenamento jurídico.

Ademais, esta abordagem econômica, principalmente em se tratando de crimes cometidos com a finalidade de aumentar o patrimônio privado ou de assegurar o proveito obtido com as condutas criminosas, pode e deve ser utilizada não somente para definir as políticas públicas, mas também para compreender as organizações criminosas, entendidas como grupos organizados que buscam, evidentemente, maximizar os seus lucros e diminuir os riscos. Em outras palavras, a abordagem econômica do direito oferece excelentes ferramentas para uma análise dos comportamentos criminosos, quer sejam individuais, quer sejam coletivos.

Percebe-se, portanto, a necessidade de uma investigação do tema sob os prismas da criminologia e da AED, os quais chegam até a se confundirem, em certas oportunidades, em virtude da matéria deste estudo.

Nesse intuito, será ofertada uma síntese sobre o entendimento legislativo e judicial aplicado àqueles que cometem delitos fiscais, principalmente aqueles vazados nos arts. $1^{\circ}$ e $2^{\circ}$ da Lei $n^{\circ} 8.137 / 90$, bem como nos arts. 168-A e 337-A do Código Pe- 
nal, enfatizando-se a extinção da punibilidade pelo pagamento aplicado aos crimes tributários lato sensu. Desse modo, a análise envolverá os crimes tributários em sua acepção ampla, englobando tanto os delitos tributários stricto sensu quanto os crimes previdenciários.

Desse modo, quanto aos fatores analisados racionalmente pelos infratores que optam pela prática das condutas definidas como delitos fiscais, principalmente em virtude da previsão de extinção da punibilidade pelo pagamento, será analisado se a legislação relativa a esta liberação da pena incentiva o pagamento dos tributos ou, ao contrário, estimula os contribuintes a ocultarem mais e mais dados fiscais, ampliando exponencialmente a sonegação tributária.

\section{Breves Considerações Jurídicas sobre a Extinção da Punibilidade em Virtude do Pagamento do Débito Fiscal nos Crimes Tributários no Brasil}

A origem do instituto da extinção de punibilidade penal, através do pagamento do débito tributário, encontra-se na doutrina e no ordenamento jurídico alemão (SÁNCHEZ RÍOS, 2003, p. 138). Com efeito, a previsão dos meios de regularização fiscal que obstam a punibilidade penal nos crimes fiscais existem nas legislações da Alemanha e da Áustria há mais de um século (IGLESIAS RÍO, 2003, p. 85).

Atualmente, está entre as normas alemãs (Abgabenordnung - §371) 2 e austríacas (Finanzstrafgesetz - § 29), ao isentar da pena

2 Os delitos tributários, na Alemanha, estão previstos naquele que se pode chamar de Código Tributário alemão (Abgabenordnung), e não no Código Penal. O Abgabenordnung (AO) prevê, ao tratar dos casos de defraudação tributária previstos no § 370 da mesma lei: “§ 371 Autodenúncia em caso de evasão fiscal. (1) Quem, nas hipóteses do $\S 370$, retificar ou completar dados incompletos perante a autoridade fiscal ou comunicar os dados omitidos, ficará impune quanto a este aspecto; (2) A isenção não ocorrerá quando: 1 . Antes da retificação, complemento ou comunicação: 
o contribuinte em face do interesse patrimonial do Estado em aumentar a arrecadação tributária, fazendo aflorar algumas fontes arrecadatórias antes ocultas, sendo chamada pelos germânicos de "autodenúncia liberadora de pena"3.

Em 1995, com grande similitude, esta liberação de pena foi incluída no Código Penal da Espanha, prevista atualmente no art. 305.4 da Ley Orgánica 10/19954. Naquele país, os juristas a denominam “escusa absolutória” (IGLESIAS RÍO, 2003, p. 37),

a) um servidor da autoridade fiscal houver comparecido para a fiscalização ou para a investigação de um delito fiscal ou uma infração administrativa tributária ou; b) haja sido notificado ao autor ou a seu representante legal do início do procedimento penal ou de imposição de multas pelo fato ou; 2 . Haja sido descoberto o fato no momento da retificação, complemento ou comunicação, no todo ou em parte, e o autor o sabia ou deveria supor sua existência em uma apreciação razoável da situação de fato; (3) Se as reduções fiscais já se houverem produzido ou se já houverem sido obtidas as vantagens fiscais, somente terá lugar a impunidade de um participante no fato quando pague os impostos sonegados em seu favor dentro do prazo fixado para ele; (4) Se a denúncia prevista no $\S 153$ for prestada oportuna e devidamente, não se perseguirá penalmente o terceiro que haja omitido a apresentação das declarações indicadas no $\S 153$ ou as haja apresentado de forma inexata ou incompleta, salvo se ele ou seu representante houvesse sido notificado anteriormente do início de um procedimento penal ou de imposição de multas pelo fato. Se o terceiro houver agido para seu próprio benefício, será aplicado o número 3." (Livre tradução).

3 Nomenclatura utilizada segundo apontamentos de Martínez-Buján Pérez (2002, p. 95 et seq.) e Iglesias Río (2003, p. 31).

4 O Código Penal Espanhol estabelece, no art. 305, 4: "Se considerará regularizada la situación tributaria cuando se haya procedido por el obligado tributario al completo reconocimiento y pago de la deuda tributaria, antes de que por la Administración Tributaria se le haya notificado el inicio de actuaciones de comprobación o investigación tendentes a la determinación de las deudas tributarias objeto de la regularización o, en el caso de que tales actuaciones no se hubieran producido, antes de que el Ministerio Fiscal, el Abogado del Estado o el representante procesal de la Administración autonómica, foral o local de que se trate, interponga querella o denuncia contra aquél dirigida, o antes de que el Ministerio Fiscal o el Juez de Instrucción realicen actuaciones que le permitan tener conocimiento formal de la iniciación de diligencias. Asimismo, los efectos de la regularización prevista en el párrafo anterior resultarán aplicables cuando se satisfagan deudas tributarias una vez prescrito el derecho de la Administración a su determinación en vía administrativa. La regularización por el obligado tributario de su situación tributaria impedirá que se le persiga por las posibles irregularidades contables u otras falsedades instrumentales que, exclusivamente en relación a la deuda tributaria objeto de regularización, el mismo pudiera haber cometido con carácter previo a la regularización de su situación tributaria." (Grifou-se) 
por entenderem que a regularização fiscal realizada pelo contribuinte configura uma causa pessoal de exclusão da pena.

Ressalte-se, entretanto, que a anulação da pena tem como requisito, tanto na Alemanha, quanto na Áustria e na Espanha, que a regularização (voluntária) da situação tributária pelo contribuinte ocorra antes da intervenção da Administração Pública (início da atividade de fiscalização) ou da atuação dos órgãos de persecução penal (MARTÍNEZ BUJÁN-PEREZ, 1998, p. 65).

O mesmo instituto foi incluído na legislação italiana há cerca de três anos (D.LGS. 158/2015, que modificou o art. 13 do D.LGS. 74/2000) $)^{5}$, possuindo enorme semelhança com a extinção da punibilidade prevista na Alemanha, inclusive quanto ao prazo para efetuar a autodenúncia, a qual deverá ser anterior ao início do procedimento fiscal ou penal (GAMBOGI, 2016, p. 380-392).

No Brasil, a Lei no 4.729/65 estabeleceu a possibilidade de extinção da punibilidade nos delitos tributários, além de ser a

5 O Decreto Legislativo italiano n ${ }^{\circ} 74 / 2000$ prevê, no seu art. 13: “Causa di non punibilità. Pagamento del debito tributario. 1. I reati di cui agli articoli 10-bis, 10-ter e 10-quater, comma 1, non sono punibili se, prima della dichiarazione di apertura del dibattimento di primo grado, i debiti tributari, comprese sanzioni amministrative e interessi, sono stati estinti mediante integrale pagamento degli importi dovuti, anche a seguito delle speciali procedure conciliative e di adesione all'accertamento previste dalle norme tributarie, nonché del ravvedimento operoso. 2. I reati di cui agli articoli 4 e 5 non sono punibili se i debiti tributari, comprese sanzioni e interessi, sono stati estinti mediante integrale pagamento degli importi dovuti, a seguito del ravvedimento operoso o della presentazione della dichiarazione omessa entro il termine di presentazione della dichiarazione relativa al periodo d'imposta successivo, sempre ché il ravvedimento o la presentazione siano intervenuti prima che l'autore del reato abbia avuto formale conoscenza di accessi, ispezioni, verifiche o dell'inizio di qualunque attività di accertamento amministrativo o di procedimenti penali. 3. Qualora, prima della dichiarazione di apertura del dibattimento di primo grado, il debito tributario sia in fase di estinzione mediante rateizzazione, anche ai fini dell'applicabilità dell'articolo 13-bis, è dato un termine di tre mesi per il pagamento del debito residuo. In tal caso la prescrizione è sospesa. Il Giudice ha facoltà di prorogare tale termine una sola volta per non oltre tre mesi, qualora lo ritenga necessario, ferma restando la sospensione della prescrizione." (Grifou-se) 
primeira a criminalizar as condutas de sonegação fiscal em nosso País, trazendo em seu art. $2^{\underline{o}}$ a seguinte redação:

Art. $2^{\circ}$ Extingue-se a punibilidade dos crimes previstos nesta Lei quando o agente promover o recolhimento do tributo devido, antes de ter início, na esfera administrativa, a ação fiscal própria. (Grifou-se).

Após, a Lei no 8.137/90 estendeu a possibilidade de extinção da punibilidade mediante pagamento também aos casos de contribuição social, ampliando ainda o prazo para o pagamento até o recebimento da denúncia, com a seguinte dicção:

Art. 14. Extingue-se a punibilidade dos crimes definidos nos arts. $1^{\circ}$ a $3^{\circ}$ quando o agente promover o pagamento de tributo ou contribuição social, inclusive acessórios, antes do recebimento da denúncia. (Grifou-se).

Após diversas mudanças ocorridas na legislação brasileira, que não cabe reproduzir neste trabalho em virtude do objeto de estudo, a Lei no 12.382/2011 alterou a Lei no 9.430/1996, cujo art. 83 passou a ter a seguinte redação:

Art. 83. A representação fiscal para fins penais relativa aos crimes contra a ordem tributária previstos nos arts. $1^{\underline{0}}$ e $2^{\underline{ }}$ da Lei $n^{\circ}$ 8.137, de 27 de dezembro de 1990, e aos crimes contra a Previdência Social, previstos nos arts. 168-A e 337-A do Decreto-Lei no 2.848, de 7 de dezembro de 1940 (Código Penal), será encaminhada ao Ministério Público depois de proferida a decisão final, na esfera administrativa, sobre a exigência fiscal do crédito tributário correspondente.

[...]

$\S 2^{\underline{o}}$ É suspensa a pretensão punitiva do Estado referente aos crimes previstos no caput, durante o período em que a pessoa física ou a pessoa jurídica relacionada com o agente dos aludidos crimes estiver incluída no parcelamento, desde que o pedido de parcelamento tenha sido formalizado antes do recebimento da denúncia criminal. 


\section{$[\ldots]$}

$\S 4^{\underline{o}}$ Extingue-se a punibilidade dos crimes referidos no caput quando a pessoa física ou a pessoa jurídica relacionada com o agente efetuar o pagamento integral dos débitos oriundos de tributos, inclusive acessórios, que tiverem sido objeto de concessão de parcelamento.

\section{$[\ldots]$}

$\S 6^{0}$ As disposições contidas no caput do art. 34 da Lei $n^{\circ}$ 9.249, de 26 de dezembro de 1995, aplicam-se aos processos administrativos e aos inquéritos e processos em curso, desde que não recebida a denúncia pelo juiz. (Grifou-se).

Cabe referir, ainda, que após a publicação da Lei $\mathrm{n}^{\mathbf{o}}$ $8.137 / 90$, manifestou-se uma clara instabilidade na diretriz político-criminal brasileira, quanto à liberação da pena em face do pagamento do débito fiscal. Efetivamente, ocorreram várias mudanças no marco temporal que permite ao infrator usufruir do benefício da extinção da punibilidade, mas ficou evidente um movimento de ampliação do prazo para pagamento do tributo. Além disso, a Lei 9.964/00 estabeleceu a suspensão da pretensão punitiva do Estado a quem tivesse sido admitido no REFIS ${ }^{6}$ até o recebimento da denúncia.

Desse modo, abordadas as previsões legais, deve-se ressaltar também o entendimento do Supremo Tribunal Federal sobre a extinção da punibilidade pelo pagamento do débito tributário, após diversas manifestações sobre o tema. Com efeito, as decisões emanadas do Pleno da Suprema Corte brasileira $^{7}$ são no sentido de que será reconhecida a extinção

6 O REFIS é um programa de recuperação fiscal, para refinanciamento das dívidas fiscais (prevendo longos e suaves parcelamentos, além de perdão ou diminuição de multas e juros), destinado a regularizar os créditos da União decorrentes de débitos referentes a tributos e contribuições administrados por três órgãos: Secretaria da Receita Federal (SRF), Procuradoria Geral da Fazenda Nacional (PGFN) e Instituto Nacional do Seguro Social (INSS).

7 A respeito da extinção da punibilidade nos crimes fiscais, vejam-se os julgados: Embargos de Declaração da Ação Penal n 516/DF; Informativo do STF n 731; Ação 
da punibilidade pelo pagamento quando o acusado: a. efetuar o pagamento direto até o trânsito em julgado da condenação criminal; ou b. quando efetuar o pagamento integral do parcelamento do débito tributário formalizado antes do recebimento da denúncia ${ }^{8}$.

\section{A Análise Racional dos Riscos e dos Benefícios dos Crimes Advindos dos Crimes Tributários no Brasil}

A metodologia da Análise Econômica do Direito (AED), quando voltada ao Direito Penal, trouxe importantes avanços para a Criminologia, pois possibilitou verificar em boa medida as causas das condutas criminosas, as formas mais eficientes e eficazes de preveni-las e reprimi-las, bem como os resultados alcançados pelas alternativas empregadas, como leciona Marcos Valadão (2011, p. 238) ${ }^{9}$.

Efetivamente, a abordagem econômica do direito tem proporcionado notáveis mecanismos de análise criminológica, como percebe o jurista Gico Junior (2010):

Penal n 613/TO; e Recurso Ordinário em Habeas Corpus nº 128.245/SP).

8 Cabe referir que há decisões mais recentes da Segunda Turma do Supremo Tribunal Federal (AP 613/TO, julg. em 2014) e também do Superior Tribunal de Justiça no sentido de que o pagamento direto do débito tributário pode ser realizado a qualquer momento, mesmo após o trânsito em julgado da condenação penal, resultando na extinção da punibilidade dos delitos fiscais. A respeito, quanto ao STJ, devem-se citar o Habeas Corpus n. 362478/SP, Relator Min. Jorge Mussi, Quinta Turma, julgado em 14.09.2017, publicado no DJe de 20.09.2017, e o Habeas Corpus HC 180.993/SP, Relator Min. Jorge Mussi, Quinta Turma, julgado em 13.12.2011, publicado no DJe 19/12/2011.

9 Em artigo no qual analisa os crimes de sonegação fiscal (com enfoque criminológico e econômico), Marcos Valadão (2011, p. 238) acrescenta que Cesare Beccaria e Jeremy Bentham deram início, no século XVIII, à tentativa de racionalizar ou encontrar um nexo na imposição das penas, "[...] com efeitos de retribuição (punição na proporção da seriedade do crime), ressocialização (reabilitação), incapacitação, reparação, o custo da imposição da pena e a prevenção (dissuasão) decorrente da sua imposição, o que se aproxima de uma análise econômica." 
Como escolhas devem ser realizadas, os agentes econômicos ponderam os custos e os beneficios de cada alternativa, adotando a conduta que, dadas as suas condições e circunstâncias, lhes traz mais bem-estar. Dizemos, então, que a conduta dos agentes econômicos é racional maximizadora. [...] A grande implicação desse postulado para a juseconomia é que se os agentes econômicos ponderam custos e beneficios na hora de decidir, então, uma alteração em sua estrutura de incentivos poderá levá-los a adotar outra conduta, a realizar outra escotha. [...] Todo o direito é construído sobre a premissa implícita de que as pessoas responderão a incentivos. Criminosos cometerão mais ou menos crimes se as penas forem mais ou menos brandas, se as chances de condenação forem maiores ou menores, se houver mais ou menos oportunidades em outras atividades mais atrativas. As pessoas tomarão mais ou menos cuidado se forem ou não responsabilizadas pelos danos que causarem a terceiros. [...] Os exemplos são incontáveis.

Nessa seara, Gary Becker apresentou em 1968 o artigo “Crime e Castigo: Uma Abordagem Econômica”, inserindo algumas técnicas analítico-econômicas (incluindo equações) muito bem elaboradas, arvorando-se em estudos nos quais considerou que a ação criminosa deriva de uma opção racional do infrator, após sopesar os possíveis ganhos e perdas provenientes de sua prática delituosa (utilidade): o proveito econômico viabilizado pelo crime, a probabilidade de ser flagrado e de sofrer sanção, a eventual perda de ganhos no período em que estiver ocasionalmente encarcerado, entre outros fatores desta natureza.

Após, vários acadêmicos expuseram estudos que conservaram (em sua essência) a ideia elementar de Becker, embora criticassem o trabalho deste ${ }^{10}$.

10 Trata-se de artigo que trouxe novos métodos e importantes discussões para a definição de políticas públicas (e também privadas) de prevenção e repressão a condutas ilícitas. Efetivamente, após as novas luzes lançadas por Gari Becker, sucederam-se diversos outros pensadores voltados para a Economic Analysis of Law, como Richard Posner, destacando-se aqueles que deram especial ênfase ao estudo da sonegação fiscal, como Michael Allingham e Agnar Sandmo (Income Tax Evasion: A Theoretical Analysis. 
Alguns anos depois, Allingham e Sandmo (1972) trouxeram outra relevante proposta, utilizando um modelo microeconômico voltado ao estudo específico da sonegação tributária, com base na teoria da utilidade esperada de von Neumann e Morgenstern. Os autores delinearam a sonegação do imposto de renda como um procedimento em que a decisão é tomada de uma forma racional, ponderando que a sonegação é um ativo de risco, diante da possibilidade de descoberta da fraude e da consequente sanção, possibilitando maximizar uma função de utilidade esperada.

Nesse rumo, Siqueira e Ramos (2006, p. 401) descreveram as linhas basilares dos estudos de Allingham e Sandmo (que inauguraram a análise econômica da sonegação fiscal), acrescentando que outros investigadores criticaram duramente os modelos puramente econômicos, sustentando que a sonegação fiscal não poderia ser compreendida com base somente nos estímulos financeiros previstos nas normas jurídicas:

Todas as hipóteses desse modelo básico foram objeto de críticas, e modelos teóricos baseados em hipóteses alternativas foram desenvolvidos tentando introduzir formalmente outros fatores que parecem ser relevantes para a decisão individual de evadir [leia-se evasão entendida como ilícita]. Uma extensão imediata foi permitir que o indivíduo escolhesse a renda a declarar juntamente com outras variáveis adicionais, tais como a oferta de trabalho, proposta por Pencavel (1979) e Cowell (1981), ou a escolha ocupacional, sugerida por Pestieau e Possen (1991), e esquemas complementares de elisão fiscal, como implementado por Cross e Shaw (1982). Penas alternativas e alíquotas não-lineares foram consideradas por Pencavel (1979) e Kesselman (1989), e o impacto da complexidade e incerteza sobre outros parâmetros fiscais foi analisado por Alm (1988) e Scotchmer e Slemrod (1989). Ao constatar que

Journal of Public Economics, n. 1, Pennsylvania, 1972), Frank Cowell e James Gordon (Unwillingness to pay: Tax Evasion and Public Good Provision, Journal of Public Economics, n. 36, Pennsylvania, 1988). 
um número crescente de indivíduos costuma pagar profissionais para a elaboração de suas declarações de rendimentos, $o$ efeito deste comportamento sobre a evasão foi examinado por Scotchmer (1989) e Reinganum e Wilde (1991). Ademais, como alguns indivíduos recebem algum serviço do governo por seus impostos pagos, Cowell e Gordon (1988) mostraram que os serviços prestados pelo governo afetam as decisões de evasão, ou seja, os indivíduos pagam tributos porque eles valoram o que eles recebem em troca, e eles pagam mais à medida que o governo é mais efetivo em prover o que eles valorizam. (Wadhawan; Gray, 1998)."

Posteriormente, Brown e Reynolds (1973) acrescentaram outro fator à equação de Becker, incluindo a riqueza inicial do criminoso ao modelo microeconômico, arrematando que o indivíduo que possui uma riqueza inicial alta tende a somente praticar condutas delituosas que viabilizem um ganho relevante em comparação com a sua riqueza inicial, conciliando o estudo com o crime de sonegação fiscal e com grande parte dos demais crimes de "colarinho branco".

Dessa forma, o modelo beckeriano foi levemente modificado na proposta de Brown e Reynolds, acrescendo-se uma avaliação quanto à probabilidade de não ser preso e condenado e o ganho financeiro (utilidade da sonegação tributária), subtraindo-se a probabilidade de ser preso e condenado e o ganho financeiro, considerando os custos da condenação. Assim, adequando-se o modelo de Becker àquele proposto por Brown e Reynolds, podem-se analisar as probabilidades e a utilidade da prática das condutas delituosas tributárias.

Nesse intuito, adaptando-se o modelo apresentado por Alencar (2010, p. 229), conforme proposta de Marcos Valadão (2011, p. 239), chega-se à seguinte equação: 


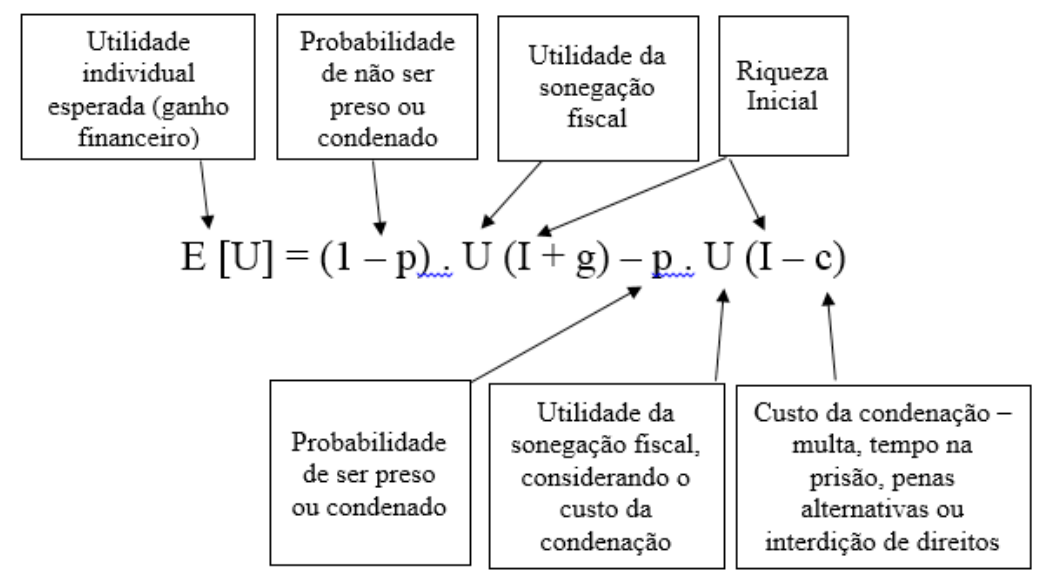

GRÁFICO 1 - equação para análise econômica da sonegação fiscal no Brasil

Ao descrever esta equação, Marcos Valadão (2011, p. 239) anota:

No modelo acima, "E[U]" representa a utilidade individual esperada derivada do cometimento do ilícito, ou seja, é uma função da utilidade decorrente do ilícito, que pode ser entendida simplesmente, no caso do crime tributário, como o ganho financeiro. A variável " $p$ " representa a probabilidade de ser condenado (sendo $0 \leq p \leq 1)$, e, portanto, $(1-p$ ) representa a possibilidade de não ser condenado. Desta forma, quanto menor a probabilidade de ser condenado, maior a utilidade derivada [do] ato criminoso. "U" é também uma função utilidade $U(I+g)$ relacionada ao ganho apropriado (" $g$ ") derivado do crime de sonegação e " $I$ " a riqueza inicial. De acordo com o modelo teórico da utilidade marginal decrescente, indivíduos que possuam uma quantidade de riqueza inicial alta tendem a somente cometer atividades ilícitas que propiciem um ganho considerável em relação à sua riqueza inicial. Em relação ao segundo termo da função utilidade individual esperada "p.U $(I-c)$ " representa o lado negativo do ilícito, isto é, a punição, ou melhor dizendo, o efeito da pena. O termo considera a probabilidade de o delinquente ser condenado em suas ações ilícitas representada pela letra " $p$ ". A variável " $c$ " é o custo da condenação que pode ser uma multa, o custo repre- 
sentado pelo tempo passado na prisão, ou custo representado pelo cumprimento de penas alternativas ou de interdição de direitos. No segundo termo, quanto maior a riqueza inicial "I" menor impacto a punição terá para o infrator.

Desse modo, os elementos desta equação devem ser analisados separadamente, aplicando-se a legislação brasileira referente aos crimes de sonegação tributária (em sentido lato).

Quanto à utilidade individual esperada, ou ganho financeiro, analisa-se que, "[...] em 2016, a Carga Tributária Bruta (CTB) atingiu 32,38\%, contra 32,11\% em 2015 [...]", segundo estudo da Secretaria da Receita Federal brasileira (2017, p. 1), baseando-se também nos dados do IBGE (Instituto Brasileiro de Geografia Estatística). Dessa forma, o ganho esperado através da sonegação fiscal é de cerca de $32 \%$ em relação ao valor dos fatos geradores ${ }^{11}$ de tributos que tenham ocorrido ${ }^{12}$.

Quanto à riqueza inicial, como anotado por Marcos Valadão (2011, p. 239), conforme o modelo teórico da utilidade marginal decrescente, aqueles que têm uma riqueza inicial alta possuem a tendência de praticarem condutas criminosas que viabilizem um ganho considerável em relação à respectiva riqueza inicial, ou seja, o estado econômico no momento de decidir pelo cometimento ou não da conduta delituosa.

11 O Código Tributário Nacional estabelece: “Art. 114. Fato gerador da obrigação principal é a situação definida em lei como necessária e suficiente à sua ocorrência. Art. 115. Fato gerador da obrigação acessória é qualquer situação que, na forma da legislação aplicável, impõe a prática ou a abstenção de ato que não configure obrigação principal." Em síntese, fato gerador é a situação de fato (hipótese tributária), prevista na lei de modo prévio, genérico e abstrato, que, quando ocorre no mundo fático, faz com que se materialize o direito e surja a obrigação tributária, seja esta principal ou acessória.

12 No breve espaço deste estudo, não serão tratados os demais ganhos esperados, como a utilização dos valores sonegados como capital de giro e/ou investimentos, nem os prejuízos causados aos concorrentes e aos demais empreendedores que efetuam os pagamentos dos tributos de modo tempestivo e completo. Do mesmo modo, não serão discutidos os danos causados às missões constitucionalmente atribuídas aos governos, principalmente para manutenção e promoção dos direitos fundamentais através do Estado. 
No que tange à probabilidade de não ser preso ou condenado, destaca-se que é altamente improvável que o delinquente que pratique as condutas delituosas vazadas nos arts. $1^{\circ}$ ou $2^{\circ}$ da Lei $n^{\circ}$ 8.137/90, e nos arts. 168-A ou 337-A do Código Penal, venha a ser preso ou condenado. De fato, como o infrator pode se ver livre da sanção penal se efetuar o pagamento do débito fiscal (principal e acessórios) até o trânsito em julgado da condenação penal (ou mesmo após, conforme decisão recente da Segunda Turma do STF e algumas decisões do STJ), até mesmo o sonegador habitual dificilmente será sancionado penalmente por esses crimes.

Efetivamente, uma vez que um processo penal no Brasil leva em média 3 anos e 1 mês para ser julgado em primeira instância, e cerca de 1 ano e 1 mês para ser julgado em segunda instância, conforme dados publicados pelo Conselho Nacional de Justiça brasileiro (2017, p. 141-142), o sonegador fiscal possui cerca de 4 anos e 2 meses para efetuar o pagamento da dívida fiscal e ter sua pena extinta, após o início da ação penal. Acrescente-se que este prazo para finalização do processo penal pode ser aumentado, em caso de recursos ao Superior Tribunal de Justiça e/ou ao Supremo Tribunal Federal. Assim, repita-se, verifica-se o prazo de cerca de 4 anos e 2 meses, em média, para que o delinquente fiscal efetue o pagamento dos débitos tributários e obtenha a liberação da pena, e este lapso temporal refere-se somente à ação penal, perante a justiça criminal (federal ou estadual).

No entanto, no Brasil, mediante súmula vinculante da Suprema Corte ${ }^{13}$, foi firmado o entendimento de que as condutas dos contribuintes infratores somente poderão ser reputadas típicas penalmente (nos crimes tributários materiais ${ }^{14}$ ) após a constituição

13 A súmula vinculante $\mathrm{n}^{\mathrm{0}} \mathbf{2 4}$ do Supremo Tribunal Federal brasileiro está assim redigida: “Não se tipifica crime material contra a ordem tributária, previsto no art. 1ํ, incisos I a IV, da Lei no 8.137/90, antes do lançamento definitivo do tributo."

14 Comente-se que a súmula vinculante no 24 do STF gera diversas controvérsias doutrinárias e jurisprudenciais quanto aos delitos fiscais, inclusive no que se refere ao próprio art. $1^{\mathrm{o}}$ da Lei $\mathrm{n}^{\mathrm{o}} 8.137 / 90$. De fato, parte dos doutrinadores e intérpretes 
definitiva do crédito tributário, ou seja, somente depois da conclusão de eventual processo administrativo fiscal em que forem discutidas os pontos controversos referentes aos tributos (e eventuais encargos acessórios) apontados pelo Fisco, possibilitando retardar muito mais o recolhimento dos tributos e o início da ação penal.

\section{Assim, qualquer atuação persecutória criminal do Estado} somente pode ser aplicada após, no mínimo, a conclusão do processo administrativo fiscal referente ao tributo exigido do contribuinte. Nesse vértice, apesar da previsão legal de que a Administração Fazendária federal deve expedir decisão administrativa no prazo (máximo) de 360 dias após o protocolo de petições, defesas ou recursos administrativos dos contribuintes no procedimento administrativo-tributário ${ }^{15}$, uma pesquisa da Fundação Getúlio Vargas revela que o tempo médio de julgamento administrativo fiscal (incluindo primeira e segunda instâncias) pode durar cerca de 5 anos, em média, segundo a amostragem analisada (FGV, 2009, p. 26), apesar de estudo mais recente (CGU e TCU, 2016, p. 9) evidenciar que o tempo médio de conclusão de procedimento administrativo fiscal de segunda instância, perante o Conselho Administrativo de Recursos Fiscais, em 2014 já era superior a 5 anos.

\footnotetext{
da lei entendem que, pelo fato do inciso $\mathrm{V}$ e do parágrafo único do art. $1^{\underline{0}}$ da Lei $\mathrm{n}^{\underline{0}}$ $8.137 / 90$ não terem constado na súmula vinculante significa que essas condutas foram reputadas como caracterizadoras de crime formal. De outro vértice, diversos outros doutrinadores e magistrados entendem que não houve qualquer manifestação do STF quanto ao inciso $\mathrm{V}$ e ao parágrafo único, e que ambos também seriam crimes materiais, dependentes da conclusão dos procedimentos administrativos para a configuração das condutas incriminadas. Quanto ao art. 168-A, o STF o havia considerado um crime formal a partir de 1998, mas em 2008 uma decisão do Pleno da Suprema Corte brasileira manifestou o entendimento de que se trata de um crime omissivo material (Agravo Regimental no Inquérito nº 2.537/GO. Pleno do STF. Rel. Min. Marco Aurélio, julg. 10.03.2008, publ. DJ 12.06.2008). Por seu turno, o delito tributário previsto no art. 337-A, nos seus incisos I a III, é considerado material, dependendo do resultado supressão ou redução do tributo e, portanto, da conclusão do processo administrativotributário.

15 A Lei 11.457/2007, que dispõe sobre a Administração Tributária Federal brasileira, prevê: “[...] Art. 24. É obrigatório que seja proferida decisão administrativa no prazo máximo de 360 (trezentos e sessenta) dias a contar do protocolo de petições, defesas ou recursos administrativos do contribuinte. [...]."
} 
Entretanto, durante ou após o processo administrativo fiscal, o contribuinte pode (também) ingressar com ação civil perante o Poder Judiciário, com o fim de discutir as exações fiscais exigidas pela Administração Fazendária. Tratam-se de processos judiciais que podem durar anos, quando o contribuinte obtiver decisão do juízo (em caráter liminar) que suspenda o processo administrativo tributário ou a eficácia do débito administrativamente constituído até decisão final no processo judicial. Nesse rumo, uma ação judicial civil, no Brasil, costuma levar (em média) 2 anos e 7 meses para ser sentenciada na primeira instância, e 9 meses para o julgamento em segunda instância. Assim, cerca de 3 anos e 4 meses são necessários para que o processo seja julgado no Brasil, em caso de recurso do contribuinte para o respectivo tribunal, conforme estudo apresentado pelo Conselho Nacional de Justiça brasileiro (2017, p. 133).

Em outras palavras, somando-se o tempo mediano dos processos administrativos fiscais com a apresentação de recurso ao CARF, de 5 anos (FGV, 2009, p. 26; CGU e TCU, 2016, p. 9), com o tempo de discussão em processo judicial tributário (se for este o caso), de aproximadamente 3 anos e 4 meses (CNJ, 2017, p. 133), se houver julgamento em segunda instância, acrescendo-se o tempo mediano de 4 anos e 2 meses (CNJ, 2017, p. 141-142), referente à ação penal se o contribuinte recorrer ao respectivo tribunal, conclui-se que o sonegador tributário possui, em média, 12 anos e 6 meses para pagar as dívidas tributárias e ser agraciado com a extinção da punibilidade, após o início da ação fiscalizatória que eventualmente tenha descoberto a infração incriminada.

De outra banda, se não for proferida decisão judicial suspendendo o processo criminal $^{16}$ ou a eficácia da constitui27774/SP, Recurso ordinário em habeas corpus, Relator Min. Ribeiro Dantas, 
ção do débito tributário (em ação anulatória da constituição do crédito tributário), o tempo mediano concedido ao sonegador para saldar a dívida fiscal e ver extinta a sanção penal será de 9 anos e 2 meses.

No entanto, este prazo pode ser ampliado, perceba-se, se o contribuinte recorrer ao Superior Tribunal de Justiça ou ao Supremo Tribunal Federal, lembrando-se que esses recursos podem ser interpostos tanto no decorrer da ação judicial tributária quanto durante a ação penal.

Reitere-se, então, que o infrator terá cerca de 12 anos e 6 meses para utilizar os recursos financeiros que não usou para pagar os tributos (mediante sonegação fiscal) como bem lhe aprouver, para investimentos ou como capital de giro, por exemplo, pois precisa pagar a dívida tributária somente se estiver na iminência de ser condenado criminalmente (ou mesmo após, conforme decisão da Segunda Turma do STF e alguns julgados do STJ). ${ }^{17}$

Quinta Turma, julgado em 12/12/2017, publicado no DJe 19/12/2017; e RHC 34159/ SC, Recurso ordinário em habeas corpus, Relator Min. Ribeiro Dantas, Quinta Turma, julgado em 12/12/2017, publicado no DJe 19/12/2017. Nessas decisões, a Quinta Turma do STJ reiterou que há entendimento pacificado naquela Corte Superiora sobre a independência entre as esferas judiciais cível e criminal, mas ponderou que a "[...] conclusão alcançada pelo juízo cível afetou diretamente o lançamento do tributo, maculando a própria constituição do crédito tributário, razão pela qual mostra-se prudente aguardar o julgamento definitivo na esfera cível." Assim, suspendeu o processo penal e/ou inquérito policial até a conclusão do processo civil.

17 Repita-se que, infelizmente, já existe entendimento da Segunda Turma do STF no sentido de que mesmo o pagamento do débito tributário após o trânsito em julgado da condenação penal concede a extinção da punibilidade ao infrator, conforme AP 613/TO, julgada em 2014. O Superior Tribunal de Justiça já decidiu no sentido de que "Não há como se interpretar o referido dispositivo legal de outro modo, senão considerando que o pagamento do tributo, a qualquer tempo, até mesmo após o advento do trânsito em julgado da sentença penal condenatória, é causa de extinção da punibilidade do acusado." (Superior Tribunal de Justiça. Habeas Corpus n. 362478/SP, Relator Min. Jorge Mussi, Quinta Turma, j. em 14/09/2017, p. no DJe de 20/09/2017). 
Desse modo, quanto aos custos de uma possível condenação, configurados por eventual tempo na prisão, multas, interdição de direitos ou outras penas alternativas, deve-se reiterar que a extinção da punibilidade pelo pagamento da dívida fiscal pode ser concedida a qualquer tempo, conforme entendimento do Supremo Tribunal Federal, a mais alta corte do Poder Judiciário brasileiro.

Percebe-se, então, que praticamente não existe risco de uma sanção penal devido à prática das condutas criminosas fiscais, sendo raríssimo o encarceramento. Efetivamente, um número muito pequeno de pessoas cumprem pena por condutas previstas nos crimes fiscais, como deixam claros os dados referentes ao Estado de São Paulo, que é a Unidade da Federação que efetua a maior arrecadação de tributos federais do Brasil $(41,06 \%)$, contendo $21,71 \%$ da população brasileira: ${ }^{18} 19$

18 Segundo o relatório anual da Secretaria de Receita Federal, no ano de 2017, foram arrecadados R\$1.342.407.672.349,62 no Brasil em tributos federais, e no Estado de São Paulo foram apurados R \$551.240.959.040,48, equivalendo a 41,06 \% da arrecadação federal. O Estado de São Paulo possui também a maior população, de 45.094 .866 de habitantes, correspondendo a $21,71 \%$ da população brasileira, de um total de 207.660.929 habitantes, no ano de 2017, segundo dados do IBGE (2017).

19 Revela-se importante destacar que os autores de crimes fiscais, julgados pela Justiça Federal ou pela Justiça Estadual, salvo raras exceções, cumprem pena nos sistemas penitenciários estaduais, caracterizando a pertinência da análise dos dados relativos ao sistema prisional estadual. De fato, o Departamento Penitenciário Nacional (DEPEN), de nível federal, tem por missão, em suma, o isolamento e a custódia de líderes de organizações criminosas e presos de alta periculosidade, que possam comprometer a ordem e segurança pública. Desse modo, os autores dos delitos fiscais, em virtude das características dos crimes (normalmente praticados sem violência ou grave ameaça), raramente cumprem pena nas penitenciárias administradas pelo DEPEN e, portanto, são recolhidos em instituições prisionais dos Estados. 

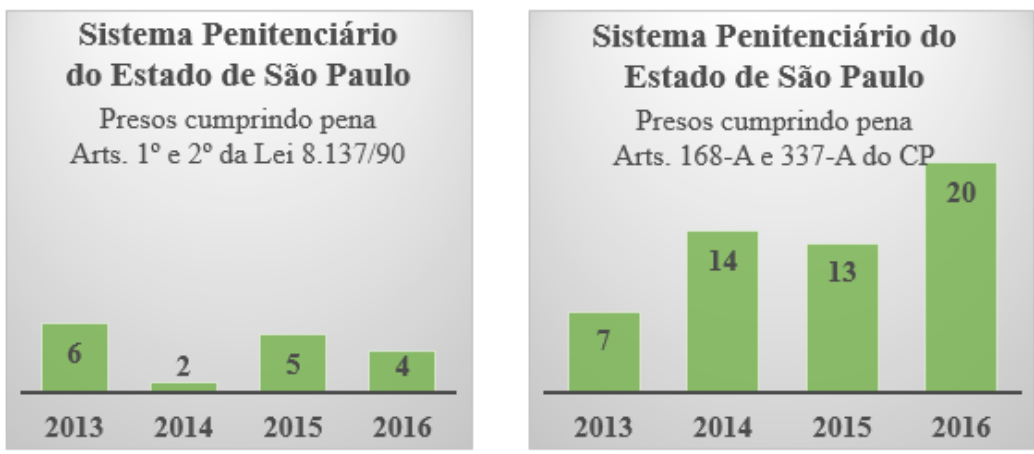

GRÁFICO 2 - número de presos do Estado de São Paulo por crimes tributários

Fonte: Elaborado por Rodrigo Luís Ziembowicz, com base nos dados apresentados pela Secretaria Estadual da Administração Penitenciária do Estado de São Paulo, em 20.06.2018 (e-SIC SP 42891189862).

Ademais, nem sequer efeitos relativos à reincidência serão aplicados a esses casos, ou seja, sempre que houver o pagamento do débito tributário (a qualquer tempo), não ocorrerá qualquer registro penal em desfavor do contribuinte faltoso, nem mesmo será impedida uma nova concessão da extinção da pena em caso de reincidência na mesma fraude e/ou sonegação.

Neste vértice, algumas normas brasileiras ${ }^{20}$ têm, inclusive, concedido até mesmo o perdão das multas aplicadas nos processos administrativos instaurados face às infrações fiscais, intensificando o estímulo à prática da sonegação tributária e previdenciária, em claro antagonismo com a autodenúncia espontânea

20 Revela-se um incentivo à sonegação, em desfavor do contribuinte honesto que pagou os tributos na quantia e no tempo devidos. Nesse vértice, os reiterados planos de recuperação fiscal (REFIS), que vêm permitindo o parcelamento de débitos tributários e concedendo o perdão ou uma significante redução das multas e demais sanções aplicadas aos contribuintes faltosos, mesmo àqueles que reiteradamente efetuam o pagamento impontual, também incentivam o não pagamento dos tributos previstos. Mencionem-se o REFIS 1 (Programa de Recuperação Fiscal - Lei 9.964/2000); REFIS 2 ("PAES" - Lei 10.684/2003; REFIS 3 ("PAEX" - MP 303/2006); REFIS 4 ("REFIS da Crise" e "REFIS da Copa" - Lei 11.941/2009 por conversão da MP 449/2008, com várias prorrogações posteriores do prazo para adesão ao programa); REFIS das Autarquias e Fundações (art. 65 da Lei 12.249/2010); REFIS dos Bancos (art. 39 da Lei 12.865/2013); REFIS da Crise (Lei 13.496/2017). 
estabelecida no art. 138 do Código Tributário Nacional ${ }^{21}$, em que é exigida a regularização dos registros anterior a qualquer procedimento administrativo ou medida de fiscalização, relacionados com a infração, para que seja concedido o perdão das sanções administrativas.

Assim, percebe-se que esta isenção da punibilidade por meio do pagamento do débito tributário, concebida pela nossa política fiscal e penal, premia o sonegador. Efetivamente, a equação apresentada neste estudo deixa transparecer que o risco (ou possibilidade) de ser descoberto praticando a sonegação fiscal, bem como o custo de eventual condenação (tempo na prisão, multa, interdição de direitos ou penas alternativas), são os elementos persuasivos que poderiam estimular o contribuinte a pagar correta e tempestivamente os tributos.

No entanto, sopesando-se algumas das dificuldades da fiscalização tributária federal brasileira, em virtude do acanhado número de auditores fiscais (aproximadamente dez mil para fiscalizarem um país de dimensões e população continental), e dos também insuficientes recursos materiais e estruturais para promover a fiscalização (proporcionalmente à extensão territorial e à quantidade de pessoas físicas e jurídicas ${ }^{22}$ a serem auditadas), ainda que tenham ocorrido avanços viabilizados pela informatização dos sistemas, pondera-se que apenas uma pequena parcela das fraudes fiscais é constatada.

21 O Código Tributário Nacional brasileiro prevê: “[...] Art. 138. A responsabilidade é excluída pela denúncia espontânea da infração, acompanhada, se for o caso, do pagamento do tributo devido e dos juros de mora, ou do depósito da importância arbitrada pela autoridade administrativa, quando o montante do tributo dependa de apuração. Parágrafo único. Não se considera espontânea a denúncia apresentada após o início de qualquer procedimento administrativo ou medida de fiscalização, relacionados com a infração."

22 O IBGE (2016, p. 27) divulgou o as estatísticas do Cadastro Central de Empresas de 2014, ressaltando que em 31.12.2014 o Brasil possuía 5.103.357 empresas em funcionamento. 
Lamentavelmente, até mesmo este pequeno percentual de fraudes descobertas pela Administração Fazendária, quando submetido ao sistema em vigor, resulta em processos administrativos e/ou judiciais civis e criminais que levam vários anos para serem julgados.

Em sendo assim, há apenas uma pequena probabilidade do infrator ser flagrado praticando fraudes tributárias e, se este contribuinte faltoso for descoberto, poderá aguardar vários anos antes de saldar a dívida fiscal, somando-se o período de disputa administrativa, de discussão judicial tributária (se for o caso) e, depois, do processo penal.

Com efeito, quando o legislador permite que o sonegador contumaz permaneça impune criminalmente, mesmo que tenha provocado prejuízos milionários (ou bilionários) ao erário público, inviabilizando a concessão dos benefícios que esses recursos poderiam fornecer à sociedade, inclusive podendo efetuar o recolhimento do débito fiscal somente quando se aproximar a condenação penal (na última instância), premia o parasitismo e estimula a sonegação, além de negar o direito fundamental dos demais cidadãos à justa divisão dos custos do Estado. ${ }^{23}$

Ademais, o instituto da extinção da punibilidade concede um regime diferenciado aos delitos fiscais e aumenta a sensação

23 Em importante estudo, Depeyre (2016, p. 138) desvela a necessidade premente do Estado e da sociedade batalharem (em união de esforços) contra o parasitismo constituído por aqueles que não contribuem para o financiamento do Estado: "A inteligência tributária convida à luta contra todos os parasitismos. Isto significa concretamente que a atenção deve se concentrar sobre todos aqueles que escapam totalmente dos tributos, embora a tendência natural da Administração Pública e do legislador seja de regular sempre aqueles que já estão inscritos no sistema, esquecendo aqueles que estão fora do sistema, muito mais difíceis de alcançar. Ações podem ser tomadas com urgência se considerarmos o custo elevadíssimo das proibições inaplicáveis e a postura econômica agressiva daqueles que estão fora do sistema." (Livre tradução). Após, o autor assevera que se trata de uma questão de sobrevivência, e que é necessário ousar e mudar normas e pensamentos para que ninguém escape à justa tributação. 
de impunidade, desestimulando a honestidade fiscal e incitando à prática dos crimes tributários. Efetivamente, quem efetuará o pagamento voluntário se não houver sanção penal para o descumprimento criminoso dos deveres fiscais?! ${ }^{24}$

Efetivamente, nos Estados Democráticos de Direito contemporâneos, de relevante cariz social, com um considerável conjunto de atribuições constitucionalmente previstas, há a necessidade de tutela penal do bem jurídico sob estudo, principalmente quando se tratar de crimes fiscais ou previdenciários de grandes somas em desfavor do erário público, indiretamente atingindo as funções sociais e de desenvolvimento a cargo do Estado. Destaca-se, também, que o direito a uma ordem econômica e financeira saudável viabiliza direta e indiretamente a proteção a direitos fundamentais, no sentido de proporcionar uma vida com um mínimo de dignidade (principalmente para os menos afortunados) através do Estado.

Efetivamente, o sistema penal tributário atual concede um regime diverso aos crimes fiscais e aumenta em muito a sensação de impunidade, ou pior, até mesmo estimula a prática da sonegação fiscal ${ }^{25}$, tolerando "[...] que o sonegador contumaz e

24 Ojurista Ricardo Echavarría (2014, p. 04:11) afirma que “[...] la Hacienda Pública merece y necesita protección penal porque sólo es posible realizar controles o inspecciones aleatórias para verificar el correcto cumplimiento de los deberes tributários, siendo esto uma oportunidade que puede ser aprovechada por los deudores para no cumplir sus obligaciones. A ello se suma que el adecuado funcionamento de la actividad financeira requiere de la participación de los contribuyntes, tanto a través de la presentación de la declaración y pago de la deuda tributaria, como em ocasiones liquidando la obligación tributaria. Estas circunstancias hacen de la Hacienda Pública um acreedor vulnerable, lo que justifica su protección por vía penal y permite rechazar la opinión que negó la existência de um bien jurídico en el Derecho penal tributário."

25 Conforme Nabarrete Neto (1997, p. 788), “[...] a punibilidade estatal deveria ser de tal molde a não possibilitar a reprodução, seja da conduta, seja do infrator. A solução presente cria o vício mental do sonegador de que as consequências de seu insucesso na prática delitiva podem ser evitadas pela quitação do tributo ou contribuição social. [...] o fato não se circunscreve apenas ao campo financeiro, mas diz com o infrator, que interpreta a ordem jurídica e forma nociva e, por isso, está inclinado a infringi-la repetidamente. A punibilidade estatal tem a ver com a própria essência do Estado. 
rico se exima da responsabilidade pela infração cometida, enquanto que o contribuinte de boa-fé, mas pobre, é punido." (ROTHMANN, 1995, p. 826) ${ }^{26}$.

Desse modo, a reintrodução da extinção da punibilidade em nosso ordenamento através da Lei $n^{\circ}$ 9.249/95, segundo Roberto Podval (1996, p. 125), caracterizou um grande equívoco do legislador e um retrocesso, asseverando que novamente empregou-se uma política que estimula a sonegação, pois os infratores que cometem os crimes tributários mediante vontade livre e consciente de fraudar a Administração Fazendária, diante da remota probabilidade de serem descobertos, necessitam apenas pagar o débito ao Fisco se forem flagrados, evitando tanto o processo quanto a punição criminal. Após, o autor arremata que isto representa uma enorme injustiça, por que o empresário trabalhador e correto, que não sonega e paga os tributos honestamente, caso enfrente uma crise financeira e não consiga recolher os tributos momentaneamente, possivelmente será processado e condenado criminalmente, mesmo que seus registros e declarações fiscais estejam em ordem.

No mesmo rumo, o jurista alemão Tipke adverte que, se ocorre uma "[...] aplicação não uniforme da lei, se a violação da lei, tolerada pelo Estado, tornar-se regra, a escolha de alguns indivíduos - os quais são tratados, excepcionalmente, conforme a lei - representa uma arbitrariedade." Posteriormente, o tributarista germânico conclui a análise deste ponto, anotando que "[...] a evasão constituirá um ato de legítima defesa para o estabeleci-

Àqueles que ameaçam ou violam valores caros à sociedade, a organização política reserva-lhes a pena, cujos fins podem ser os mais variados, mas um deles certamente é garantir-se que o infrator conforme-se à ordem jurídica existente e não reproduza a conduta proibida."

26 Conforme Silveira (1996, p. 139), “[...] o infrator, o delinquente, corre tão-somente um único risco: o de ser pegado com a boca na botija e ter de pagar o que pretendia sonegar. Se ele não tiver dinheiro, vai processado e preso; se, ao contrário, for rico e poderoso, se livra solto... Como sempre!" 
mento da igualdade, de fato, da tributação cuja responsabilidade é do Estado." (TIPKE apud ROTHMANN, 1995, p. 819-820).

Aliás, a extinção da punibilidade nesses crimes fiscais leva o magistrado Nabarrete Neto (1997, p. 780-781) a anotar que “[...] a realidade e impressão geral são as de impunidade". O jurista conclui que esta contrariedade (entre a sensação de impunidade e a incorporação de instrumentos para afastar a punibilidade nos precitados casos) “[...] só pode ser explicada pela distância que separa o povo em geral e a elite dominante que controla ou mais influencia o Estado."

Percebe-se, de fato, que a liberação da pena ${ }^{27}$ sob estudo permite concluir que a sonegação compensa, face à impossibilidade dos órgãos de fiscalização tributária auditarem com profundidade todos os dados e os registros das dezenas de milhões de pessoas físicas e jurídicas no Brasil, efetuando-se muitas fiscalizações por amostragem ${ }^{28} 29$.

27 Consta na exposição de motivos do Decreto-Lei português 28/84, de 20 de janeiro de 1984, em seu item 9: "[...] Abundantes estudos criminológicos apontam nesse sentido: o delinquente contra a economia é particularmente sensível à ameaça da pena privativa da liberdade e, em contrapartida, indiferente às penas pecuniárias, já que ao assumir os comportamentos criminosos conta com uma margem de risco em que inclui os custos eventuais da sujeição a sanções deste último tipo."

28 O penalista Echavarría Ramírez (2014, p. 04:11) sustenta que "[...] la Hacienda Pública merece y necesita protección penal porque sólo es posible realizar controles o inspecciones aleatórias para verificar el correcto cumplimiento de los deberes tributários, siendo esto una oportunidade que puede ser aprovechada por los deudores para no cumplir sus obligaciones. A ello se suma que el adecuado funcionamento de la actividad financeira requiere de la participación de los contribuyntes, tanto a través de la presentación de la declaración y pago de la deuda tributaria, como en ocasiones liquidando la obligación tributaria. Estas circunstancias hacen de la Hacienda Pública um acreedor vulnerable, lo que justifica su protección por vía penal y permite rechazar la opinión que negó la existência de um bien jurídico en el Derecho penal tributario."

29 Nesse tema, o autor Juary Silva (1998, p. 22) leciona: “Os meios repressivos à inadimplência e à fraude estão sempre vários corpos atrás desta, jamais a alcançando. Nas épocas em que o organismo estatal se debilita essa defasagem ainda mais se acentua, uma vez que o legislador, às vezes, abandonando a técnica jurídica e a boa política fiscal, busca açodadamente recuperar o tempo perdido." 
Nesse sentido, o instituto da extinção da punibilidade pelo pagamento atualmente utilizado no Brasil, que tem sua origem nos ordenamentos alemão e austríaco (com a função de trazer à tona os fatos geradores até então ocultados das autoridades fazendárias), serve apenas para fazer com que os contribuintes sejam induzidos a omitir mais e mais informações tributárias, aumentando exponencialmente a sonegação fiscal.

Assim, conforme adverte Borsio (2009, p. 295), ao apresentar uma visão sistêmica atualizada sobre os delitos fiscais, os bons pagadores constatam que os sonegadores permanecem impunes ao se beneficiarem da extinção da punição, através do pagamento ou do parcelamento, causando uma "ciranda da evasão tributária", em consequência causando um aumento da carga tributária.

Em virtude dessa situação, Figueiredo Dias (1984, p. 69) afirma que em todos os Estados "[...] perpassa hoje um sentimento generalizado de injustiça estrutural, em relação ao qual a impunibilidade dos delinquentes econômicos ou a sua menor punição injustificada adquirem acentuada ressonância simbólica."

Verifica-se que, infelizmente, as mudanças na legislação desfiguraram o instituto da extinção da punibilidade pelo pagamento da dívida fiscal, inicialmente importada do ordenamento jurídico alemão com o fim de fazer aflorar fatos geradores de tributos ocultados do Estado ${ }^{30}$, pois em vez de estimular a autodenúncia fiscal (antes do início da ação fiscal ou da denúncia perante o Poder Judiciário), conservando-se os fins da prevenção geral e especial da pena, o sistema atualmente empregado no Brasil encoraja a sonegação.

30 Estes fatos ocultos são tratados por Iglesias Río como uma elevada cifra negra (2003, p. 37-43), em face da dificuldade de descobrimento das fraudes (2003, p. 43-53). 
Faz-se necessária, portanto, uma adequada instrumentalização do Estado para enfrentar a macrocriminalidade econômica, dos denominados "crimes de colarinho branco" ou "delitos de cavalheiros", especialmente os crimes fiscais, a lavagem de dinheiro e a contumaz utilização de paraísos fiscais em transações empresariais de elevadas somas.

Ademais, repita-se, diante das evidentes limitações da capacidade do Fisco de apurar e de comprovar fatos geradores dissimulados ou ocultados, principalmente no complexo e volumoso conjunto de normas tributárias em vigor no Brasil, nitidamente as previsões penais dos crimes tributários, tornadas sem efeito pela extinção da pena pelo pagamento, tornam-se ineficazes e oferecem proteção penal insuficiente aos bens jurídicos tutelados.

\section{Conchusões}

Os estudos realizados neste ensaio visaram a verificar, simultaneamente sob os prismas da criminologia e da Economic Analysis of Law, se a possibilidade de extinção da punibilidade criminal pelo pagamento do débito tributário, quando a quitação da dívida fiscal for realizada antes do trânsito em julgado da condenação penal, incentiva a correta prestação de informações e o pagamento do débito tributário apurado pela Administração Fazendária ou, ao contrário, incentiva o contribuinte a sonegar informações sobre os fatos geradores e a evitar de forma fraudulenta o recolhimento de tributos de forma integral e tempestiva.

Nesse sentido, percebeu-se que os contribuintes e, principalmente, as maiores empresas (inclusive as transnacionais), sopesam os custos, os riscos e os benefícios de cada uma das escolhas possíveis ao tomarem suas decisões, numa evidente conduta racional maximizadora dos lucros, entre outros fatores ponderados ao escolherem entre o cometimento ou não dos crimes tributários. 
No mesmo rumo, a Análise Econômica do Direito trouxe novas luzes à Criminologia, emprestando instrumentos e modelos que permitiram uma análise criminológica mais apurada, principalmente nas investigações voltadas às organizações criminosas nos Estados Unidos e na elaboração das respectivas políticas públicas em resposta a esta criminalidade. De fato, infelizmente as organizações criminosas evoluíram muito, tornando-se fluidas e multifacetárias, utilizando verdadeiras estruturas empresariais não somente para lavar dinheiro, mas também para administrar os empreendimentos criminosos, tendo sempre como principal objetivo um resultado econômico, tornando extremamente relevante a utilização das ferramentas e dos modelos ofertados pela Análise Econômica do Direito para sua compreensão e repressão.

Este fato se revela ainda mais importante em virtude do crescimento da macrocriminalidade (ou atual criminalidade organizada econômica e financeira, fluida e de alcance global), que vem substituindo e ocupando os espaços da microcriminalidade (ou organizações criminais clássicas).

Assim, analisadas essas vertentes criminológica e econômica relativas especificamente aos crimes tributários, utilizandose técnicas que podem ser adaptadas para a compreensão e para a investigação científica dos demais crimes previstos no ordenamento jurídico, foi elaborada equação que permitiu a visualização do tratamento político-criminal atualmente dispensado aos delitos fiscais.

Nesse sentido, faz-se necessária a proteção penal dos bens jurídicos imediato (erário público) e mediatos (funções atribuídas constitucionalmente ao Estado, principalmente na promoção e proteção dos direitos fundamentais) tutelados pelos tipos penais tributários. 
Entretanto, aplicada a Análise Econômica do Direito ao instituto da extinção da punibilidade pelo pagamento da dívida fiscal, principalmente ao visualizar-se a equação presente neste estudo, verifica-se que: praticamente inexiste o risco de ser flagrado e posteriormente sancionado (administrativa ou penalmente) pela prática dos delitos tributários previstos em nosso ordenamento jurídico; há risco relativamente baixo de ser flagrado pela fiscalização fazendária; caso o infrator seja descoberto, poderá evitar o pagamento dos débitos durante aproximadamente 9 anos e 2 meses, isto é, praticamente inexistem riscos de uma condenação penal; até mesmo eventuais multas administrativotributárias, face às constantes reedições dos programas de refinanciamento do débito tributário, com o perdão das multas e/ ou descontos generosos na sanção, tornam inócuas até mesmo as sanções previstas. Em outras palavras, o sistema penal-tributário é quase que totalmente ineficaz, deixando claro que a política fiscal-criminal brasileira praticamente não possui persuasão capaz de dissuadir e, portanto, prevenir, a prática dos delitos fiscais.

Assim, o Estado nem mesmo respeita o direito de todo contribuinte honesto, cumpridor das normas, de exigir providências do Estado para que todos os demais cidadãos sejam tributados na mesma proporção, de acordo com a capacidade contributiva, isto é, nega-se o direito de exigir que todos sejam submetidos à mesma cota de sacrifício para o bem comum.

Ao mesmo tempo, o Estado não se atenta ao fato de que, para promover o desenvolvimento e a produção de riquezas e bens, é extremamente necessária uma ordem econômica e financeira saudável. Entretanto, esta não será possível se, por exemplo, os concorrentes de mesmo porte e ramo empresarial forem submetidos a cargas tributárias diferenciadas, em virtude da sonegação ou de outras fraudes semelhantes, sem a adequada prevenção e apuração dos desvios de conduta pelo Estado. 
Ademais, a previsão de delitos fiscais, acompanhados da possibilidade de extinção da punibilidade pelo pagamento a qualquer tempo da dívida tributária, permite-nos deduzir que esta pena tem por único fundamento a cobrança de dívida fiscal, criando ameaça de prisão por dívida, retratando uma situação totalmente incompatível com nossa Constituição e com os direitos fundamentais, desobedecendo à vedação do excesso estatal. De fato, não é permitido ao Estado "monetarizar" ou "vender" a sanção penal em troca de recursos financeiros.

Em outro vértice, é vedado ao Estado oferecer tutela penal insuficiente, após o reconhecimento da legitimidade penal dos bens jurídicos protegidos, isto é, deve-se proporcionar a adequada proteção penal, como imperativo de tutela, diante dos bens sob salvaguarda mediata (direitos fundamentais) nas previsões penais-fiscais.

Desse modo, entende-se que o legislador pátrio deve conceder a extinção da punibilidade pelo pagamento da dívida fiscal somente quando a autodenúncia (voluntária) do contribuinte faltoso for realizada antes do início da ação fiscal, conforme constava no art. $2^{\circ}$ da Lei $n^{\circ} 4.729 / 65$, preservando os direitos e princípios fundamentais previstos na Carta Política (liberdade, dignidade da pessoa humana, isonomia, proporcionalidade etc), os quais devem conduzir também a aplicação do Direito Penal (que deve ser um sistema único, coerente e sistematizado).

Isso exposto, entende-se o pagamento posterior ao início da ação fiscal deverá acatar às regras gerais do Direito Penal, permitindo o cumprimento dos princípios constitucionais da isonomia e da proporcionalidade, além de afastar a inconstitucional intimidação por prisão civil por dívida. Efetivamente, em nosso ordenamento jurídico, a recomposição dos danos em delitos sem violência ou grave ameaça tem como efeitos: se for realizada vo- 
luntariamente até o recebimento da denúncia, reduzirá a pena de um a dois terços (arrependimento posterior - art. 16 do $\mathrm{CP}$ ); quando a reparação do dano for efetuada entre o recebimento da denúncia e o julgamento representará uma atenuante, a ser considerada na dosimetria da pena (art. 65, III, b, do CP).

Acredita-se, neste rumo, que as modificações sugeridas promoverão um retorno à credibilidade do sistema penal-tributário, acatando sobretudo as previsões constitucionais relativas aos direitos fundamentais, bem como os princípios conquistados ao longo de séculos de progresso da humanidade e da doutrina criminal, além de restituir a confiança nas instituições que participam da persecução penal e viabilizando uma melhoria das prestações estatais oferecidas à sociedade.

Em síntese, deixar-se-á de estimular a fraude (e todo o desvalor que a conduta criminosa fiscal encerra), pois atualmente o ordenamento jurídico beneficia a quem salda os débitos quando descoberto, como o sonegador contumaz que planeja antecipadamente a sonegação (mantendo recursos para pagamento quando flagrado), ao mesmo tempo em que mantém a persecução penal, com a ameaça de pena de prisão, apenas em desfavor de quem não consegue quitar a dívida tributária, embora possa ter agido com boa-fé e apenas esteja insolvente momentaneamente.

\section{REFERÊNCIAS BIBLIOGRÁFICAS}

ALLINGHAM, Michael; SANDMO, Agnar. Income Tax Evasion: A Theoretical Analysis. Journal of Public Economics. n. 1. Pennsylvania, 1972.

ANDRADE, José Carlos Vieira de. Os Direitos Fundamentais na Constituição Portuguesa de 1976. 4. ed. Coimbra: Almedina, 2009.

BARQUERO ESTEVAN, Juan Manuel. La función del tributo en 
el Estado Social y Democrático de Derecho. Madrid: Centro de Estudios Políticos y Constitucionales, 2002.

BECKER, Gary. Crime and Punishment: An Economic Approach. In: The Journal of Political Economy. vol. 76. n. 2. Mar Apr. Columbia, 1968.

BONAVIDES, Paulo. Curso de Direito Constitucional. 14. Ed. São Paulo: Malheiros, 2004.

BORSIO, Marcelo Fernando. Investigações nos Crimes Previdenciários em face do Inquérito Policial Federal: limitações constitucionais. In: CUNHA, Rogério Sanches; TAQUES, Pedro; GOMES, Luiz Flávio. (Coord.). Limites Constitucionais da Investigação. São Paulo: RT, 2009.

BRASIL. Conselho Nacional de Justiça. Justiça em Números 2017: ano-base 2016. Brasília: CNJ, 2017. Disponível em: <http://www.cnj.jus.br/files/conteudo/arquivo/2017/12/ b60a659e5d5cb79337945c1dd137496c.pdf>. Acessado em maio de 2018.

. Decreto-Lei n. 2.848, de 07 de dezembro de 1940. Código Penal. Disponível em: <http://www.planalto.gov.br/ ccivil_03/decreto-lei/Del2848compilado.htm>. Acesso em abril de 2017.

. Lei n. 4.729, de 14 de julho de 1965. Define o crime de sonegação fiscal e dá outras providências. Disponível em: <http://www.planalto.gov.br/ccivil_03/leis/1950-1969/ L4729.htm>. Acesso em abril de 2017.

. Lei n. 5.172, de 25 de outubro de 1966. Dispõe sobre o Sistema Tributário Nacional e institui normas gerais de direito tributário aplicáveis à União, Estados e Municípios. Disponível em: <http://www.planalto.gov.br/ccivil_03/ leis/L5172.htm>. Acesso em abril de 2017. . Lei n. 8.137, de 27 de dezembro de 1990. Define crimes 
contra a ordem tributária, econômica e contra as relações de consumo, e dá outras providências. Disponível em: $<$ http://www.planalto.gov.br/ccivil_03/leis/L8137.htm>. Acesso em abril de 2017. . Lei n. 8.383, de 30 de dezembro de 1991. Institui a Unidade Fiscal de Referência, altera a legislação do imposto de renda e dá outras providências. Disponível em: <http:// www.planalto.gov.br/ccivil_03/leis/L8383.htm>. Acesso em abril de 2017. . Lei n. 9.249, de 26 de dezembro de 1995. Altera a legislação do imposto de renda das pessoas jurídicas, bem como da contribuição social sobre o lucro líquido, e dá outras providências. Disponível em: <http://www.planalto.gov. br/ccivil_03/leis/L9249.htm>. Acesso em abril de 2017.

. Lei no 9.430, de 27 de dezembro de 1996. Dispõe sobre a legislação tributária federal, as contribuições para a seguridade social, o processo administrativo de consulta e dá outras providências.. Disponível em: <http://www. planalto.gov.br/ccivil_03/leis/L9430.htm>. Acesso em abril de 2017.

. Lei n. 9.964, de 10 de abril de 2000. Institui o Programa de Recuperação Fiscal - Refis e dá outras providências. Disponível em: <http://www.planalto.gov.br/ccivil_03/ leis/L9964.htm>. Acesso em abril de 2017.

. Lei n. 10.684, de 30 de maio de 2003. Altera a legislação tributária, dispõe sobre parcelamento de débitos junto à Secretaria da Receita Federal, à Procuradoria-Geral da Fazenda Nacional e ao Instituto Nacional do Seguro Social e dá outras providências. Disponível em: <http://www. planalto.gov.br/ccivil_03/leis/2003/L10.684.htm>. Acesso em abril de 2017. 
. Lei n. 11.941, de 27 de maio de 2009. Altera a legislação tributária federal relativa ao parcelamento ordinário de débitos tributários e dá outras providências. Disponível em: <http://www.planalto.gov.br/ccivil_03/_ato20072010/2009/lei/111941.htm>. Acesso em abril de 2017.

. Lei $\mathrm{n}^{\mathrm{o}}$ 12.382, de 25 de fevereiro de 2011. Dispõe sobre o valor do salário mínimo em 2011, altera a Lei n⿳0 9.430, de 27 de dezembro de 1996 e dá outras providências. Disponível em: <http://www.planalto.gov.br/ccivil_03/_Ato20112014/2011/Lei/L12382.htm>. Acesso em abril de 2017.

- Secretaria da Receita Federal. Carga Tributária no Brasil em 2016: análise por tributos e bases de incidência. 2017. Disponível em: http://idg.receita.fazenda.gov.br/ dados/receitadata/estudos-e-tributarios-e-aduaneiros/ estudos-e-estatisticas/carga-tributaria-no-brasil/cargatributaria-2016.pdf. Acesso em maio de 2018.

. Supremo Tribunal Federal. Embargos de declaração na ação penal n ${ }^{\circ}$ 516, Distrito Federal. Rel. Min. Ayres Britto. Red. para Ac. Min. Luiz Fux. Data da decisão: 05/12/2013. Disponível em: <http://www.stf.jus.br//arquivo/ informativo/documento/informativo731.htm\#ED: extinção de punibilidade pelo pagamento integral de débito e prescrição retroativa - 11>. Acesso em abril de 2017.

- Supremo Tribunal Federal. Questão de ordem na ação penal n. 613, Tocantins. Rel. Min. Carmen Lúcia. Data da decisão: 15/05/2014. Disponível em: < $\quad$ http://redir.stf.jus.br/paginadorpub/paginador. jsp?docTP=TP\&docID=6017447> . Acesso em maio de 2017.

- Supremo Tribunal Federal. Segunda Turma. Recurso ordinário em habeas corpus $\mathrm{n}^{\circ} 128.245$, São Paulo, Rel. Min. Dias Toffoli. Data da decisão: 23/08/2016. Disponível em: <http://redir.stf.jus.br/paginadorpub/paginador. 
jsp?docTP=TP\&docID=11898938>. Acesso em maio de 2017.

- Tribunal de Contas da União e Controladoria-Geral da União. Avaliação da integridade do CARF. Relatório de Auditoria no 201504306. Acórdão no 1076/2016. Rel. Min. Raimundo Carreiro, TCU, Plenário, j. em 04.05.2016. Disponível em: <http://www.cgu.gov.br/noticias/2016/06/ auditoria-conjunta-entre-cgu-e-tcu-aponta-fragilidadesna-estrutura-do-carf>. Acesso em junho de 2018.

BROWN, William W.; REYNOLDS, Morgan O. Crime and "punishment": risk implications. Journal of Economic Theory, v. 6, n. 5, University of California, 1973.

BUFFON, Marciano. Tributação e Dignidade Humana: entre os direitos e os deveres fundamentais. Porto Alegre: Livraria do Advogado, 2009.

CANOTILHO, J. J. Gomes. Direito Constitucional e Teoria da Constituição. 7. Ed. Coimbra: Almedina. 2003.

CARDOSO, Alessandro Mendes. O Dever Fundamental de Recolher Tributos no Estado Democrático de Direito. Porto Alegre: Livraria do Advogado, 2014.

CHULVI, Cristina Pauner. El deber constitucional de contribuir al sostenimiento de los gastos públicos. Castellón: UniversitatJaume I, 2001.

COWELL, Frank; GORDON, James. Unwillingness to pay: Tax Evasion and Public Good Provision. Journal of Public Economics. n. 36. Pennsylvania, 1988.

ECHAVARRÍA RAMÍREZ, Ricardo. Consideraciones sobre el bien jurídico penalmente protegido por el delito de defraudación tributaria del art. 305 C. P. Español. In: Revista Electrónica de Ciencia Penal y Criminologia, Número 16, Año 2014. Granada: Universidad de Granada, 
2014. Encontrado em: http://criminet.ugr.es/recpc/16/ recpc16-04.pdf, acessado em maio de 2017.

EISELE, Andreas. A reparação do dano no Direito Penal Tributário. In: Heloísa Estellita Salomão (Coord.). Direito Penal Empresarial. v. 1. São Paulo: Dialética, 2001.

ESPANHA. Constitución Española. Boletín Oficial del Estado, de 29 de diciembre de 1978.

FIGUEIREDO DIAS, Jorge de. Sobre a autonomia dogmática do direito penal econômico - Uma reflexão à luz do novo direito penal econômico português. In: Conferência na Faculdade de Direito da Universidade de Santiago de Compostela. Santiago de Compostela: USC, 1984.

FUNDAÇÃO GETÚLIO VARGAS. Relatório Final NEF 2009: Reforma do Processo Administrativo Fiscal Federal (PAF)/ CARF. DE SANTI, Eurico Marcos Diniz (coord.). São Paulo: FGV, 2009.

GICO JR., Ivo Teixeira. Metodologia e Epistemologia da Análise Econômica do Direito. In: A Economic Analysis of Law Review, v. 1, n. 1, Jan-Jun, 2010. Disponível em: https://portalrevistas.ucb.br/index.php/EALR/article/ view/1460/1110. Acessado em maio de 2017.

IGLESIAS RÍO, Miguel Angel. La regularización fiscal en el delito de defraudación tributaria. Valencia: Tirant lo Blanch, 2003.

NABAIS, José Casalta. O Dever Fundamental de Pagar Impostos: contributo para a compreensão constitucional do Estado Fiscal Contemporâneo. Coimbra: Almedina, 1998.

- A Face Oculta dos Deveres Fundamentais. In: Revista Direito Mackenzie. ano 3. n. 2. 2002.

NABARRETE NETO, André. Extinção da Punibilidade nos Crimes contra a Ordem Tributária. 1997. In: MARTINS, Ives Gandra da Silva; BRITO, Edvaldo. (Org.). Coleção 
Doutrinas Essenciais. v. VIII. São Paulo: RT, 2011.

PODVAL, Roberto. Um grande equívoco. In: Boletim IBCCrim, Editorial. Fev. 1996.

RODRIGUES, Anabela Miranda. Contributo para a Fundamentação de um Discurso

Punitivo em Matéria Penal Fiscal. In: PODVAL, Roberto (org.). Temas de Direito Penal Econômico. São Paulo: Revista dos Tribunais, 2001.

ROTHMAN, Gerd W. A Extinção da Punibilidade nos Crimes contra a Ordem Tributária. 1995. In: MARTINS, Ives Gandra da Silva; BRITO, Edvaldo. (Org.). Coleção Doutrinas Essenciais. v. VIII. São Paulo: RT, 2011.

SÁNCHEZ RÍOS, Rodrigo. O Crime Fiscal: reflexões sobre o crime fiscal no direito brasileiro (Lei n. 8.137, de 27 de dezembro de 1990) e no direito estrangeiro, Porto Alegre: Fabris, 1998.

- Das Causas de Extinção da Punibilidade nos Delitos Econômicos. Ciência do Direito Penal Contemporânea. vol. 5. São Paulo: RT, 2003.

SIQUEIRA, Marcelo Lettieri; RAMOS, Francisco S. Evasão fiscal do imposto sobre a renda: uma análise do comportamento do contribuinte ante o sistema impositivo brasileiro. In: Economia Aplicada, v. 10, n. 3, jul./set. 2006.

TIPKE, Klaus; LANG, Joachim. Direito Tributário. 18. ed. FURQUIM, Luiz Dória (Trad.). Porto Alegre: Fabris, 2008.

VALADÃO, Marcos Aurélio Pereira. Comentários sobre as alterações tributárias à Constituição Brasileira de 1988. In: Ciência e Técnica Fiscal, nº 413, 2004. 
- Direitos Humanos e Tributação: uma concepção integradora. In: Revista Direito em Ação, v. 2, n 1, set. 2001. Brasília.

. Crimes de Sonegação Fiscal: um enfoque criminológico e econômico. In: OTERO, Paulo; ARAÚJO, Fernando; DA GAMA, João Taborda. (Orgs.). Estudos em Memória do prof. Dr. J. L. Saldanha Sanches. vol. V. set. 2011. Coimbra: Coimbra Editora, 2011. 